\title{
Genetic analysis of yield and physical traits of spring wheat grain
}

\author{
Hafiz Ghulam Muhu-Din Ahmed ${ }^{1 *}$, Abdus Salam Khan ${ }^{1}$, Muhammad Kashif ${ }^{1}$ and Sultan Habibullah \\ Khan $^{2}$ \\ ${ }^{1}$ Department of Plant Breeding and Genetics, University of Agriculture, Faisalabad, Pakistan. \\ ${ }^{2}$ Centre of Agricultural Biochemistry and Biotechnology, University of Agriculture, Faisalabad, Pakistan.
}

Revised: 27 June 2017; Accepted: 17 August 2017

\begin{abstract}
The economic value of wheat grain is determined by morphology, texture and size of grain. Very little knowledge is available about the genetic inheritance pattern of the physical characteristics of wheat grain. The mechanical properties of wheat kernel have direct or indirect link on the milling and baking quality of wheat. Six bread wheat genotypes/lines were crossed in all possible combinations in order to assess the genetic inheritance pattern and combining ability of the grain's physical properties. Additive type of gene action was involved in number of spikelets per spike, spike length, number of grains per spike, grain weight and grain area. Therefore, selection of superior plants can be done in early generations for development of better wheat genotypes. Grain yield per spike, grain width, grain length, grain height and grain sphericity having nonadditive type of gene actions clearly indicated that selection of superior plants should be postponed to later generations. The genotype 9481 was the best general combiner, while among the crosses $1 \times 3$ and $4 \times 6$ exhibited the highest positive specific combining ability in most of the prominent traits. This study will be useful for wheat breeders to develop high yielding genotypes with better grain architecture to improve the milling and baking quality of bread wheat.
\end{abstract}

Keywords: Additive, generation, grain, sphericity, texture.

\section{INTRODUCTION}

Wheat is a major food crop cultivated all over the world and is used to produce an extensive diversity of baked food products. Market and economic values of wheat are influenced by important quality traits because it depends on the morphology and texture of the grain (Lyford et al., 2005). The mechanical properties of wheat grain have a direct or indirect link on the milling and baking quality of wheat. Many scientists revealed that the grain size has an impact on wheat milling and baking qualities (Marshall et al., 1984; Berman et al., 1996). Millers prefer large, well-filled round, and uniform grains because they aim for higher quantities of flour per unit of weight. Similarly more extracts from large grains are preferred by maltsters and brewers (Dziki \& Laskowski, 2005). Smaller sized grains are considered to be harder and have inferior milling and baking properties while larger sized wheat grains have higher weight, and more endosperm (Gaines et al., 1997). Marshall et al. (1986) studied the factors which directly influence the milling yield in wheat such as grain size (GS), grain thickness (GT), grain sphericity (GSH), endosperm size (ES) and grain density (GD). They also described that an increase in grain weight and volume are directly proportional to an increase in grain length, rather than in width or height. The quality of wheat flour and yield depend on grain properties, which are considered during the milling process. These properties are strongly related to many factors, among which genetic heritage is the most important.

For effective improvement of the quality and yield of wheat, plant breeders must have a knowledge of inheritance of quality and agronomic traits. Many wheat breeders have described heterosis and combining ability of different quality and agronomic traits in wheat (Barnard et al., 2002; Dağüstü, 2008), but very little information is available on the relative genetic pattern of the physical

* Corresponding author (ahmedbreeder@gmail.com; (iD https://orcid.org/0000-0001-9104-3791)

This article is published under the Creative Commons CC-BY-ND License (http://creativecommons.org/licenses/by-nd/4.0/). This license permits use, distribution and reproduction, commercial and non-commercial, provided that the original work is properly cited and is not changed anyway. 
characteristics of bread wheat kernel. No previous studies have been reported on the inheritance pattern and genetic architecture of the kernel physical characteristics except the studies conducted by Yucel et al. (2009). They showed that there were correlation and combining ability in grain traits. Breeders use combining ability to select the parents that have maximum potential of transmitting desirable genes in the progenies (Gorjanovic \& Balalic, 2005). General combining ability (GCA) characterise the additive effects and additive $\times$ additive interaction effects (Joshi et al., 2004) that can be fixed in next generations. Specific combining ability (SCA) represents dominance epistasis (non-additive). Significance of reciprocal combining ability (REs) might be due to the cytoplasmic influences of the female parents (Topal et al., 2004; Dağüstü, 2008; Ahmed et al., 2017).

It is important to know the heritability of different grain features of bread wheat and it would be possible to use this information to increase the value of wheat in developing new high yielding genotypes with better grain architecture. Therefore, the aim of this study was to identify the gene effect and combining ability of kernel characteristics of bread wheat.

\section{METHODOLOGY}

Six varieties/lines of bread wheat (Triticum aestivum L.), namely, IQ-2000, SH-95, Aas-11, 9479, 9481 and 9486 were selected based on the diversity of their grain properties and crossed in all possible ways during 2014 - 2015. Seeds of $F_{1}$ 's were sown and established in field using the randomised complete block design with 3 replications during the season $2015-2016$ at the research station of the Department of Plant Breeding and Genetics, University of Agriculture, Faisalabad, Pakistan. All possible $30 \mathrm{~F}_{1}$ hybrids along with the 6 parents were planted in $3 \mathrm{~m}$ long single rows with intra-row and inter-row spacing of $0.10 \mathrm{~m}$ and $0.20 \mathrm{~m}$, respectively. Agronomic practices and plant protection measures were followed as per the recommended practices; NPK fertiliser was applied at the time of sowing in $1.5: 1: 1$ ratio and the plants received 4 irrigations during the whole season. Before heading time ( 90 - 95 days after sowing), the main tiller of randomly selected 10 best plants was tagged in each plot. At maturity all tagged plants were harvested by hand and data collected for spike traits such as spike length (SL), spikelets per spike (SPS), number of grains per spike (NGS) and grain yield per spike (GYS) as described by Zadoks et al. (1974), and Bell and Fisher (1994).

The same 10 plants were used for recording the physical characteristics of grains. Maintaining homogeneity, five grains from the upper, middle and lower parts of the spikes were randomly selected to measure the physical characteristics of grain. A total of 16,200 grains were observed for physical properties: 15 grains from each spikelet (5 grains from each portion) of 36 parents/crosses with 3 replications of 10 selected plants. Grain weight of the spikelet was calculated from the 15 grains and was averaged. Grain area (GA) in $\mathrm{mm}^{2}$ was calculated using the formula $[(\mathrm{GA})=13 / 11$ $(\mathrm{W}+\mathrm{H}) \mathrm{L}]$. Grain length $(\mathrm{GL})$, grain width $(\mathrm{GW})$, and grain height $(\mathrm{GH})$ were recorded using a micrometer with an accuracy of $0.01 \mathrm{~mm}$. Degree of sphericity $(\Phi)$ was calculated by using the formula $[(\Phi)=(\mathrm{De} / \mathrm{L})$ 100] as described by Mohsenin (1996), whereas the equivalent diameter was calculated using the formula $\left[(\mathrm{De})=(\mathrm{LWH})^{1 / 3}\right]$.

Analysis of variance for all scrutinised traits was accomplished using the method of Steel and Torrie (1984). Separation of the means was determined according to Duncan's multiple range test (SAS, 2002). Further, gene action and combining ability analysis of variance was done according to the method given by Griffing (1956), using Method 1 and Model II.

\section{RESULTS AND DISCUSSION}

The grand mean values, coefficient of variation (CV) and standard error (SE) of the six parents and their 30 $\mathrm{F}_{1}$ hybrids for all characteristics under consideration

Table 1: Grand means, $\mathrm{CV}$ and $\mathrm{SE}$ of some yield and physical characteristics of grains in parents and their $\mathrm{F}_{1}$ progeny in bread wheat

\begin{tabular}{lrrrrrrrrrr}
\hline $\begin{array}{l}\text { Parents/ } \\
\text { crosses }\end{array}$ & $\begin{array}{c}\text { Spikelets } \\
\text { / spike }\end{array}$ & $\begin{array}{c}\text { Spike } \\
\text { length } \\
(\mathrm{cm})\end{array}$ & $\begin{array}{c}\text { Grain } \\
\text { / spike }\end{array}$ & $\begin{array}{c}\text { Grain } \\
\text { yield/ } \\
\text { spike }(\mathrm{g})\end{array}$ & $\begin{array}{c}\text { Grain } \\
\text { weight } \\
(\mathrm{mg})\end{array}$ & $\begin{array}{c}\text { Grain } \\
\text { width } \\
(\mathrm{mm})\end{array}$ & $\begin{array}{r}\text { Grain } \\
\text { length } \\
(\mathrm{mm})\end{array}$ & $\begin{array}{c}\text { Grain } \\
\text { height } \\
(\mathrm{mm})\end{array}$ & $\begin{array}{c}\text { Grain } \\
\text { area } \\
\left(\mathrm{mm}^{2}\right)\end{array}$ & $\begin{array}{c}\text { Grain } \\
\text { sphericity } \\
\phi\end{array}$ \\
\hline Grand mean & 21.10 & 11.02 & 64.25 & 3.23 & 40.41 & 3.02 & 6.94 & 3.09 & 48.73 & 57.65 \\
CV \% & 3.88 & 9.28 & 2.15 & 4.88 & 5.55 & 5.14 & 2.46 & 2.50 & 3.66 & 3.77 \\
SE & 0.47 & 0.59 & 1.13 & 0.09 & 1.29 & 0.09 & 0.10 & 0.05 & 1.03 & 1.26 \\
\hline
\end{tabular}

$\mathrm{CV}$ : coefficient of variation; SE: standard error 
Table 2: Analysis of variance for some yield and physical characteristics of grain in Triticum aestivum L.

\begin{tabular}{lccccccccccc}
\hline Mean squares & d.f & $\begin{array}{c}\text { Spikelets } \\
\text { / spike }\end{array}$ & $\begin{array}{c}\text { Spike } \\
\text { length } \\
(\mathrm{cm})\end{array}$ & $\begin{array}{c}\text { Grain } / \\
\text { spike }\end{array}$ & $\begin{array}{c}\text { Grain } \\
\text { yield/spike } \\
(\mathrm{g})\end{array}$ & $\begin{array}{c}\text { Grain } \\
\text { weight } \\
(\mathrm{mg})\end{array}$ & $\begin{array}{c}\text { Grain } \\
\text { width } \\
(\mathrm{mm})\end{array}$ & $\begin{array}{c}\text { Grain } \\
\text { length } \\
(\mathrm{mm})\end{array}$ & $\begin{array}{c}\text { Grain } \\
\text { height } \\
(\mathrm{mm})\end{array}$ & $\begin{array}{c}\text { Grain } \\
\text { area } \\
\left(\mathrm{mm}^{2}\right)\end{array}$ & $\begin{array}{c}\text { Grain } \\
\text { sphericity } \\
\phi\end{array}$ \\
\hline Replications & 2 & 0.592 & 0.703 & 0.215 & 0.01 & 26.766 & 0.027 & 0.119 & 0.017 & 204.273 & 1.33 \\
Genotypes & 35 & $5.654^{* *}$ & $3.008^{* *}$ & $38.879^{* *}$ & $0.248^{* *}$ & $24.155^{* *}$ & $0.067^{* *}$ & $0.276^{* *}$ & $0.097^{* *}$ & $58.844^{* *}$ & $8.09^{*}$ \\
Error & 70 & 0.669 & 1.047 & 1.908 & 0.025 & 5.028 & 0.024 & 0.029 & 0.006 & 3.186 & 4.73 \\
Total & 107 & 2.29 & 1.68 & 13.97 & 0.097 & 11.69 & 0.038 & 0.111 & 0.036 & 25.150 & 5.76 \\
\hline
\end{tabular}

${ }^{*}$ and ${ }^{* *}$ indicate significant effect at 0.05 and 0.01 probability, respectively

are presented in Table 1. Analysis of variance indicated highly significant differences among parents and their $F_{1}$ hybrids for all characters except grain sphericity (Table 2).

\section{Spikelets per spike (SPS)}

After partitioning the genotypic mean squares it was found that GCA and RE mean squares were significant for spikelet per spike, while SCA effects were not significant (Table 3). Combining ability effects (Table 5) depicted that maximum GCA effects was indicated by the parent 9481 (0.84), while the lowest GCA effects was displayed by the variety Aas-11 (-0.88). The best specific performance (Table 5) was indicated by hybrid combinations $1 \times 3(0.88)$ and $3 \times 4(0.57)$, whereas the poorest SCA effects were exhibited by hybrids $1 \times 4(-1.32)$ and $1 \times 5(-0.32)$. The highest positive reciprocal effects (Table 5) was displayed by hybrid $5 \times 1$ (1.33) followed by hybrid $3 \times 1$ (1.17), while the cross $5 \times 3$ indicated the lowest reciprocal effects with a value of -1.33 . The presence of additive genetic effects revealed that it was due to greater GCA mean squares (15.296) and GCA:SCA ratio greater than 1 (5.65), as well as higher GCA variance (1.31) in the computation of variance components (Table 4). Tosun et al. (1995) and Ahmed and Mustafa (2017) also reported similar findings for this character.

Table 3: Combining ability analysis of yield and physical characteristics of grain Triticum aestivum $\mathrm{L}$.

\begin{tabular}{|c|c|c|c|c|c|c|c|c|c|c|c|}
\hline $\begin{array}{l}\text { Mean } \\
\text { squares }\end{array}$ & d.f & $\begin{array}{l}\text { Spikelets } \\
\text { / spike }\end{array}$ & $\begin{array}{l}\text { Spike } \\
\text { length } \\
(\mathrm{cm})\end{array}$ & $\begin{array}{l}\text { Grain } \\
\text { / spike }\end{array}$ & $\begin{array}{c}\text { Grain } \\
\text { yield/spike } \\
\text { (g) }\end{array}$ & $\begin{array}{c}\text { Grain } \\
\text { weight } \\
(\mathrm{mg})\end{array}$ & $\begin{array}{r}\text { Grain } \\
\text { width } \\
(\mathrm{mm})\end{array}$ & $\begin{array}{l}\text { Grain } \\
\text { length } \\
(\mathrm{mm})\end{array}$ & $\begin{array}{c}\text { Grain } \\
\text { height } \\
(\mathrm{mm})\end{array}$ & $\begin{array}{l}\text { Grain } \\
\text { area } \\
\left(\mathrm{mm}^{2}\right)\end{array}$ & $\begin{array}{c}\text { Grain } \\
\text { sphericity } \\
\phi\end{array}$ \\
\hline GCA & 5 & $15.296^{*}$ & $7.430^{* *}$ & $75.40^{*}$ & $0.288^{* *}$ & $42.44^{\mathrm{NS}}$ & $0.188^{*}$ & $0.450^{\mathrm{NS}}$ & $0.190^{* *}$ & $126.90^{\mathrm{NS}}$ & $0.86^{\mathrm{NS}}$ \\
\hline SCA & 15 & $2.704^{* *}$ & $1.399^{\mathrm{NS}}$ & $21.2^{* *}$ & $0.205^{* *}$ & $24.70^{* *}$ & $0.04^{* *}$ & $0.229^{* *}$ & $0.084^{* *}$ & $46.521^{* *}$ & $3.56^{*}$ \\
\hline $\mathrm{RE}$ & 15 & $5.389^{*}$ & $3.144^{* * *}$ & $44.3^{* *}$ & $0.277^{* *}$ & $17.50^{* *}$ & $0.050^{*}$ & $0.265^{* *}$ & $0.080^{\mathrm{NS}}$ & $48.491^{* *}$ & $2.45^{\mathrm{NS}}$ \\
\hline
\end{tabular}

NS * and **: indicate non-significant and significant effect at 0.05 and 0.01 probability, respectively

Table 4: Estimation of components of variation for combining abilities of yield and physical traits of grain in Triticum aestivum L.

\begin{tabular}{lcccccccccc}
\hline Component & $\begin{array}{c}\text { Spikelets } \\
\text { / spike }\end{array}$ & $\begin{array}{c}\text { Spike } \\
\text { length } \\
(\mathrm{cm})\end{array}$ & $\begin{array}{c}\text { Grain } \\
\text { / spike }\end{array}$ & $\begin{array}{c}\text { Grain } \\
\text { yield/spike } \\
(\mathrm{g})\end{array}$ & $\begin{array}{c}\text { Grain } \\
\text { weight } \\
(\mathrm{mg})\end{array}$ & $\begin{array}{c}\text { Grain } \\
\text { width } \\
(\mathrm{mm})\end{array}$ & $\begin{array}{c}\text { Grain } \\
\text { length } \\
(\mathrm{mm})\end{array}$ & $\begin{array}{c}\text { Grain } \\
\text { height } \\
(\mathrm{mm})\end{array}$ & $\begin{array}{c}\text { Grain } \\
\text { area } \\
\left(\mathrm{mm}^{2}\right)\end{array}$ & $\begin{array}{c}\text { Grain } \\
\text { sphericity } \\
\phi\end{array}$ \\
\hline $\mathrm{V}_{\mathrm{g}}$ & 0.656 & 0.155 & 16.185 & 0.002 & 5.534 & 0.001 & 0.001 & 0.001 & 46.609 & 0.24 \\
$\mathrm{~V}_{\mathrm{s}}$ & 0.126 & 0.073 & 0.989 & 0.009 & 1.354 & 0.003 & 0.010 & 0.004 & 2.189 & 1.23 \\
$\mathrm{~V}_{\mathrm{r}}$ & 0.971 & 0.337 & 65.607 & 0.003 & 10.392 & 0.001 & 0.002 & 0.002 & 78.453 & 0.44 \\
$\mathrm{~V}_{\mathrm{A}}\left(2 * \mathrm{~V}_{\mathrm{g}}\right)$ & 1.312 & 0.31 & 32.37 & 0.004 & 11.068 & 0.002 & 0.002 & 0.002 & 93.218 & 0.48 \\
$\mathrm{~V}_{\mathrm{D}}$ & 0.126 & 0.073 & 0.989 & 0.009 & 1.354 & 0.003 & 0.010 & 0.004 & 2.189 & 1.23 \\
\hline
\end{tabular}

$\mathrm{V}_{\mathrm{g}}=$ variance due to GCA; $\mathrm{V}_{\mathrm{s}}=$ variance due to $\mathrm{SCA} ; \mathrm{V}_{\mathrm{r}}=$ variance due to $\mathrm{RE} ; \mathrm{V}_{\mathrm{A}}=$ additive variance; $\mathrm{V}_{\mathrm{D}}=$ dominance variance 
Table 5: Estimation of general combining ability (GCA), specific combining ability (SCA) and resiprocal effect (RE) in the $\mathrm{F}_{1}$ generation for some yield and physical characteristics of grains in Triticum aestivum $\mathrm{L}$.

\begin{tabular}{|c|c|c|c|c|c|c|c|c|c|c|}
\hline Parents/crosses & SPS & SL & GS & GYS & GW & GWI & GL & GH & GA & GSH \\
\hline \multicolumn{11}{|l|}{ GCA } \\
\hline IQ-2000(1) & 0.45 & 0.34 & 1.06 & 0.04 & 1.14 & -0.02 & -0.07 & 0.03 & -0.38 & 0.42 \\
\hline Aas-11(2) & -0.88 & -0.82 & -1.78 & -0.09 & -0.70 & 0.01 & 0.00 & -0.02 & -0.14 & -0.10 \\
\hline SH-95(3) & -0.60 & -0.07 & -1.04 & -0.08 & -0.94 & -0.09 & -0.14 & -0.10 & -2.47 & 0.04 \\
\hline $9479(4)$ & -0.07 & -0.05 & -0.93 & -0.06 & -1.27 & -0.06 & -0.05 & -0.07 & -1.36 & -0.41 \\
\hline $9481(5)$ & 0.84 & 0.45 & 1.90 & 0.13 & 0.98 & 0.08 & 0.13 & 0.08 & 2.15 & 0.00 \\
\hline $9486(6)$ & 0.26 & 0.15 & 0.79 & 0.06 & 0.80 & 0.07 & 0.14 & 0.07 & 2.20 & 0.05 \\
\hline \multicolumn{11}{|l|}{ SCA } \\
\hline $1 \times 2$ & -0.18 & -0.37 & -1.03 & -0.10 & 0.32 & -0.01 & -0.06 & -0.12 & -1.46 & -0.28 \\
\hline $1 \times 3$ & 0.88 & 0.05 & 2.07 & 0.17 & 2.55 & 0.10 & 0.12 & 0.11 & 2.53 & 1.61 \\
\hline $1 \times 4$ & -1.32 & 0.35 & -2.71 & -0.28 & -2.78 & -0.09 & -0.18 & -0.12 & -2.80 & -0.34 \\
\hline $1 \times 5$ & -0.73 & 0.19 & -1.54 & -0.11 & -0.53 & 0.03 & -0.04 & -0.06 & -0.54 & 0.53 \\
\hline $1 \times 6$ & -0.32 & -0.84 & -0.76 & -0.16 & -2.85 & -0.16 & -0.44 & -0.13 & -5.41 & 2.23 \\
\hline $2 \times 3$ & 0.21 & -0.45 & 1.40 & 0.10 & -0.27 & -0.04 & 0.00 & 0.03 & -0.14 & 0.22 \\
\hline $2 \times 4$ & 0.02 & 0.02 & 0.46 & 0.17 & 0.90 & 0.06 & -0.03 & 0.09 & 0.99 & 0.60 \\
\hline $2 \times 5$ & 0.10 & -0.15 & 1.04 & -0.03 & -0.85 & 0.00 & 0.10 & 0.03 & 1.04 & 0.07 \\
\hline $2 \times 6$ & -0.15 & 0.66 & -0.51 & -0.08 & -1.76 & -0.05 & -0.06 & -0.01 & -0.93 & 0.13 \\
\hline $3 \times 4$ & 0.57 & 0.27 & 1.39 & 0.00 & 0.97 & 0.03 & 0.05 & 0.05 & 0.92 & 1.99 \\
\hline $3 \times 5$ & -0.34 & 0.77 & -0.86 & -0.06 & -2.45 & -0.13 & -0.19 & -0.18 & -3.79 & -1.59 \\
\hline $3 \times 6$ & -0.09 & -0.09 & 0.17 & -0.08 & 0.73 & 0.10 & 0.19 & 0.01 & 2.06 & -1.19 \\
\hline $4 \times 5$ & -0.20 & -0.76 & -1.97 & -0.21 & -1.78 & 0.00 & -0.06 & -0.11 & -1.38 & -0.13 \\
\hline $4 \times 6$ & 0.55 & 0.38 & 2.06 & 0.27 & 2.23 & 0.11 & 0.18 & 0.07 & 2.68 & -0.45 \\
\hline $5 \times 6$ & 0.30 & -0.12 & 0.56 & 0.10 & 1.98 & 0.02 & 0.11 & 0.14 & 2.21 & 0.18 \\
\hline \multicolumn{11}{|l|}{$\mathrm{RE}$} \\
\hline $2 \times 1$ & -1.17 & -0.50 & -2.50 & -0.02 & -1.83 & 0.01 & 0.01 & 0.05 & 0.51 & -1.01 \\
\hline $3 \times 1$ & 1.17 & 1.33 & 3.83 & 0.43 & 1.83 & 0.15 & 0.42 & 0.19 & 5.61 & 2.15 \\
\hline $4 \times 1$ & -0.17 & 0.00 & -0.50 & 0.00 & 0.83 & 0.18 & 0.30 & 0.06 & 3.83 & -0.46 \\
\hline $5 \times 1$ & 1.33 & 0.33 & 4.00 & 0.40 & 3.00 & 0.08 & 0.34 & 0.17 & 4.45 & 1.12 \\
\hline $6 \times 1$ & 0.83 & 0.67 & 2.00 & 0.13 & 0.17 & 0.11 & 0.31 & 0.01 & 2.95 & 1.42 \\
\hline $3 \times 2$ & 0.17 & 0.33 & 4.17 & 0.23 & 1.83 & -0.07 & -0.05 & 0.02 & -0.74 & -0.49 \\
\hline $4 \times 2$ & -1.50 & -1.50 & -3.00 & -0.12 & -0.33 & -0.10 & -0.19 & -0.14 & -3.26 & -1.31 \\
\hline $5 \times 2$ & -0.50 & -0.83 & -1.75 & 0.02 & -0.83 & -0.09 & -0.19 & -0.19 & -3.67 & -0.06 \\
\hline $6 \times 2$ & -1.67 & -0.33 & -4.75 & -0.28 & -2.42 & -0.01 & -0.03 & -0.21 & -1.96 & 0.52 \\
\hline $4 \times 3$ & 0.33 & -0.17 & -1.50 & -0.07 & -0.83 & -0.02 & 0.16 & 0.03 & 1.11 & 2.23 \\
\hline $5 \times 3$ & -1.33 & -0.50 & -3.08 & -0.23 & -1.33 & 0.11 & 0.24 & -0.01 & 2.28 & 0.69 \\
\hline $6 \times 3$ & 0.33 & 1.00 & -1.00 & -0.13 & -2.00 & 0.11 & 0.06 & -0.04 & 1.07 & -0.09 \\
\hline $5 \times 4$ & 0.00 & 0.33 & 0.08 & -0.17 & -1.67 & -0.02 & -0.05 & -0.10 & -1.34 & 1.12 \\
\hline $6 \times 4$ & -0.50 & 0.17 & 0.50 & -0.17 & -2.17 & -0.07 & -0.12 & -0.13 & -2.46 & 0.52 \\
\hline $6 \times 5$ & 0.83 & 0.83 & 2.17 & 0.22 & 1.83 & 0.03 & 0.13 & 0.05 & 1.57 & 0.25 \\
\hline
\end{tabular}

SPS: spikelets per spike; SL: spike length; GS: grains per spike; GYS: grain yield per spike; GW: grain weight; GWI: grain width; GL: grain length; GH: grain height; GA: grain area; GSH: grain sphericity; IQ-2000: Iqbal-2000; SH-95: Shakar-95

\section{Spike length (SL)}

Table 3 displays that the GCA and reciprocal effects mean squares were highly significant for spike length, while SCA effects mean square was not significant for this trait. Estimates of GCA revealed that parent 9481 was the best general combiner for spike length with GCA effects of 0.45 , and the poorest general combiner was Aas-11 with negative GCA effects of -0.82 . The cross combination $3 \times 5(0.77)$ indicated the highest positive SCA effects (Table 5). The cross $4 \times 5$ displayed the poorest specific combiner $(-0.77)$. Table 5 indicates that 
the maximum positive reciprocal effects was observed in the hybrid $3 \times 1$ (1.33) followed by $6 \times 3(1.00)$. Maximum negative reciprocal effect was exhibited by the cross combination $4 \times 2(-1.50)$. Mean squares due to GCA (15.29) was greater than SCA (2.704) mean squares. Similarly, the variance components also indicate that GCA variance was greater than SCA variance (Table 4). Thus, a predominant role of additive genetic effects was revealed for this trait. These results are in agreement with those of Ahmed et al. (2015b), Shahzad et al. (1998) and Iqbal and Chowdhry (2000). Additive gene effects were significant for spike length as reported by Sharma \& Sain (2003) in all cases, and Joshi et al. (2004) also explained the predominance of additive gene effects for spike length.

\section{Number of grains per spike (GPS)}

It is obvious from analysis of variance that mean squares due to SCA and reciprocal effects were highly significant, while GCA effects mean squares were significant. GCA mean squares (75.40) were much greater than SCA (21.2) mean squares as displayed in Table 3. The variance components also depict that GCA variance was greater than SCA variance, which suggests that additive genetic effects were more prominent in controlling the genetics of number of grains per spike (Table 4). The present results are also in agreement with Ali and Khan (1998) and Hamada et al. (2002) for this trait. However results of this study differ with Kumar et al. (2003), Dhayal and Sastry (2003) and Chowdhry et al. (1999) who reported non-additive genetic effects for this trait. This may be due to differences in the genetic material used and environmental conditions under which the experiment was conducted. Out of the five parents 9481 was the best combiner with maximum GCA effects (1.90) whereas Aas-11 (-1.78) was the poorest general combiner (Table 5). The best cross combination for SCA effects was $1 \times 3$ followed by $4 \times 5$, which displayed the highest values of 2.07 and 2.06 , respectively. The hybrid, which displayed the highest negative SCA effect (-2.71) was $1 \times 4$. The highest reciprocal effect (Table 5) was exhibited by hybrid $3 \times 2$ with a value of 4.17 , while the lowest reciprocal effect was shown by the cross combination $6 \times 2$ with a value of -4.75 .

\section{Grain yield per spike (GYS)}

Highly significant mean squares due to GCA, SCA and reciprocal effects can be observed in Table 3 . The components of variance (Table 4) computed to observe the nature of inheritance for the trait depicted that GCA variance was much greater than SCA variance, showing the importance of additive genetic control for grain yield. This is also explained by Hamada et al. (2002) and Ahmed et al. (2015b), who reported predominance of additive gene effects for grain yield per spike. Estimates of general, specific combining ability and reciprocal effects are presented in Table 5. Genotype 9481 exhibited the highest GCA effect of 0.13 making it the best general combiner, while genotype Aas-11 was the poorest general combiner with a GCA effect of -0.09 . Positive SCA effects were recorded in only 5 crosses. Among the 15 direct crosses producing positive SCA effects, the hybrids $4 \times 6$ and $2 \times 4$ with values 0.27 and 0.21 , respectively were the best specific crosses. The highest negative SCA effect $(-0.28)$ was found in the hybrid $1 \times 4$. Positive reciprocal effects were recorded only in eight crosses and the hybrid $6 \times 2$ had the most negative reciprocal effects with a value of 0.28 .

\section{Grain weight (GW)}

Results regarding the mean squares of GCA, SCA and reciprocal effects revealed that GCA effects were not significant while only SCA and reciprocal effects were highly significant for grain weight. Mean squares due to GCA effects were higher than mean squares due to SCA effects (Table 2). Additive gene action was revealed after the computation of variance components because GCA variances turn out to be much higher than the SCA variance (Table 4). These results are in accordance with the observations by Ekiz et al. (1998) and Topal et al. (2004). IQ-2000 proved to be the best combiner (Table 5) with the highest GCA effects (1.14) followed by 9481 and 9486 with the values of (0.98) and (0.80), respectively. The remaining three varieties showed poor performance for this trait by displaying negative GCA effects. In the case of SCA effects (Table 5) hybrid $1 \times 3$ showed excellent performance with the highest (2.55) SCA effects followed by hybrid $4 \times 6$ (2.23). The lowest specific combiner was the cross combination $1 \times 6$ with a negative value of -2.85 . Estimates of reciprocal effects (Table 5) of the crosses showed that grain weight was significant with the highest value of 3.00 in $5 \times 1$ followed by 1.83 in $6 \times 5$, but worked more negatively in $6 \times 4$.

\section{Grain width (GWI)}

The analysis of variance for combining ability revealed that mean squares due to GCA and reciprocal were significant and mean squares due to SCA were highly significant. Although mean square $(0.188)$ due to GCA effects was higher than mean square (0.04) due to SCA effects (Table 3), prevalence of non-additive gene action was revealed after the computation of variance components. The GCA variances turn out to be much 
higher than the SCA variance (Table 4). These results are in agreement with those of Yucel et al. (2009). The estimation of the general combining ability over all the parents, specific combining ability and reciprocal effects are given in Table 5. The parents have shown differences in GCA effects for grain width and parents $9481(0.08)$, 9486 (0.07) and Aas-11 (0.01) had relative high GCA effects for maximum grain width. The remaining three parents showed poor performance for this trait by displaying negative GCA effects. Fifteen of the direct cross combinations showed positive SCA effects. Among them, $4 \times 6$ was the best specific cross $(\mathrm{SCA}=0.11)$, while $1 \times 6$ was the poorest specific cross $(\mathrm{SCA}=-0.16)$. The cross combinations $4 \times 1$ with the value 0.18 and $3 \times 1$ with the value 0.15 had significant positive reciprocal effects for grain width, whereas the cross $4 \times 2$ showed negative reciprocal effects with a value of -0.10 .

\section{Grain length (GL)}

Mean squares due to GCA were not significant, while SCA and reciprocal mean squares were highly significant for this trait (Table 3). Although mean squares due to GCA (0.450) effects were higher than mean squares due to SCA (0.22) effects (Table 3) for grain length, prevalence of non-additive gene action was revealed after the computation of variance components, because SCA variance $(0.01)$ turned out to be much higher than the GCA variance 0.001 (Table 4), which suggested that non-additive genetic effects were more prominent in controlling the genetics of grain length. The present results are also in agreement with Topal et al. (2004), and Gorjanovic and Balalic (2005) indicating that GCA effects were dominant for kernel length. Parent 9486, which was one of the best general combiners for grain length had a GCA effect of 0.14 (Table 5). Maximum positive SCA effects (0.19) was found in cross combination $3 \times 6$, while minimum SCA effects $(-0.44)$ was indicated by cross combinations $1 \times 6$. The cross $3 \times 1$ indicated positive reciprocal effects $(0.42)$ (Table 5), while negative reciprocal effects ranged from $-0.03(6 \times 2)$ to $-0.19(4 \times 2)$.

\section{Grain height (GH)}

Highly significant mean squares due to GCA, SCA and reciprocal effects were observed (Table 3 ). Although the general combining ability variance $(0.190)$ was greater than specific combining ability variance $(0.084)$ as displayed in Table 3, calculations of variance components revealed that SCA effects $(0.004)$ were greater than GCA effects (0.001) (Table 4), which displayed the preponderance of non-additive genetic effects for the control of plant height. These results are in agreement with the findings of Yucel et al. (2009). The highest positive GCA effect for grain height was recorded in the parent 9481 (0.08), which turned out to be the best general combiner for this trait. Three parents out of six showed negative GCA effects, which were the poorest general combiners (Table 5). Maximum SCA effects (Table 5) were observed for crosses $5 \times 6$ and $1 \times 3$ with values of 0.14 and 0.11 , respectively, while minimum SCA effects were indicated by cross combinations $1 \times 6$ and $1 \times 2$ with values of -0.13 and -0.12 , respectively. Reciprocal effects were positive only in eight out of 15 crosses and were maximum in the cross $3 \times 1$ with a value of 0.19 .

\section{Grain area (GA)}

Table 3 displays that GCA effects mean squares were not significant, while SCA and reciprocal effects mean squares were highly significant for grain area. GCA mean squares (126.90) were much greater than SCA mean squares (46.521). The variance components also depicted that GCA variance (46.60) was greater than SCA variance (2.189) indicating the presence of additive (non-fixable) genetic effects for grain area (Table 4). These results are in agreement with those of Topal et al. (2004) and Yucel et al. (2009). In Table 5, combining ability effects showed that only two parents, 9486 (2.20) and 9481 (2.15), were the best general combiners, while the remaining four were the poorest general combiners for grain area by showing negative GCA effects. Positive SCA effects were recorded in six out of 15 cross combinations and was maximum in cross $4 \times 6$ with a value of 2.68 , while $1 \times 6$ was the poorest specific cross with highest negative SCA effects (-5.41). Positive reciprocal effects were recorded in only nine crosses and the hybrid $3 \times 1$ had the highest reciprocal effect of 5.61.

\section{Grain sphericity (GS)}

It was found that GCA and reciprocal mean squares were non-significant for grain sphericity (Table 3 ). SCA effects were, however, highly significant in this case. GCA mean squares (0.86) were lower than SCA mean squares (3.56) and similarly, the variance components also indicated that GCA variance was lower than SCA variance as displayed in Table 2. Thus, a predominant role of non-additive genetic effects was observed for grain sphericity as shown in Table 4 . These results are in agreement with Topal et al. (2004) and Yucel et al. (2009). Estimates of general combining ability in Table 5 showed that the parent IQ-2000 was the best general combiner for grain sphericity with a value of GCA $=0.42$. The poorest general combiner was 9479 with a negative GCA effect 
of -0.41. As far as the SCA effects were concerned six out of 15 crosses showed negative effects (Table 4 ). The best cross combination for SCA effects was $1 \times 6$, which displayed the highest value of 2.23. Reciprocal effects were positive only in nine out of 15 crosses and was the highest in hybrid $4 \times 3$ with a value of 2.23 .

The information regarding physical properties of wheat grains is important for setting a machine for cleaning, storing, sowing, milling, handling, and other useful purposes. Milling sieves are shaped according to the size of grains such as GL, GW and GH. For drying after harvest and during storage grain sphericity and grain area are important traits.

\section{CONCLUSION}

In this study, we observed that both additive and nonadditive components of genetic variation were present in governing the inheritance of studied traits. Among the parents 9481 was the best general combiner in most of the studied traits. In the case of SCA crosses $1 \times 3$ and $4 \times 6$ exhibited the highest positive SCA in most of the prominent traits. Non-additive gene action was present in studied parameters such as grain yield per spike, grain width, grain length, grain height and grain sphericity. Traits having non-additive type of gene actions clearly indicated that the selection of superior plants should be postponed to later generations. Characteristics with high SCA values (non-additive type of gene action) can be used for hybrid wheat production or for application of double haploid production via anther culture on F1 progenies. Additive types of gene action involved in spikelet per spike, spike length, grain per spike, grain weight, and grain area. Therefore these traits having high values of GCA (additive types of gene action), so, the selection of superior plants can be fixed in early generation for development of wheat genotypes which have these prominent traits. Significant REs on grain weight, grain length, grain width and grain area $(\mathrm{p}<$ 0.01 ), and spikelets per spike, spike length, number of grains per spike and grain yield per spike $(\mathrm{p}<0.05)$ indicate cytoplasmic influences for these traits.

Thus, it is suggested from these results that selection for the right characteristics will ensure improvement of more than one characteristic simultaneously, due to the correlation among different traits. Development of new better genotypes with better grain structures might be helpful for wheat breeders to enhance the yield potential as well as improving the milling process of grain and baking quality of wheat.

\section{Acknowledgement}

The author is thankful to the Higher Education Commission (HEC) of Pakistan for facilitating this research for $\mathrm{PhD}$ studies.

\section{REFERENCES}

1. Ahmed H.G.M.D., Khan A.S., Sadam M.S., Yasir M.H., Zahid S., Benish M. \& Khan A. (2015a). Designate the gene dose for yield related indices in spring wheat. International Journal of Biosciences 6: 396 - 401.

2. Ahmed H.G.M.D., Saddam M.S., Khan A., Fatima A., Saleem S., Hassan M., Zahid S. \& Benish M. (2015b). Genetic mechanisms of yield related morphological markers response to increase grain yield in different environment of hexaploid wheat. Journal of Bioscience and Environmental Sciences 6: 158 - 166.

3. Ahmed H.G.M.D., Khan A.S., Kashif M. \& Khan S.H. (2017). Genetic mechanism of leaf venation and stomatal traits for breeding drought tolerant lines in wheat. Bangladesh Journal of Botany 46(1): 35 - 41.

4. Ahmed H.G.M.D. \& Mustafa S. (2017). Designate the inheritance pattern of yield related indices in spring wheat. Journal of Agriculture and Basic Sciences 02(01): 50 - 57.

5. Ali A. \& Khan A.S. (1998). Combining ability studies of some morpho-physiological traits in bread wheat (Triticum aestivum L.). Pakistan Journal of Agricultural Sciences 35: $1-3$.

6. Barnard A.D., Labuschagne M.T. \& Van-niekerk H.A. (2002). Heritability estimates of bread wheat quality in the Western Cape Town province of South Africa. Euphytica 127: $115-122$.

DOI: https://doi.org/10.1023/A:1019997427305

7. Bell M.A. \& Fischer R.A. (1994). Guide to plant and crop sampling: measurements and observations for agronomic and physiological research in small grain cereals. Wheat Special Report No 32, International Maize and Wheat Improvement Centre (CIMMYT), Mexico.

8. Berman M., Bason M.L., Ellison R., Peden G. \& Wrigley C.W. (1996). Image analysis of whole grain to screen for flour milling yield in wheat breeding. Cereal Chemistry 73 : $323-327$.

9. Chowdhry M.A., Rabbani G., Subhani G.M. \& Khaliq L. (1999). Combining ability studies for some polygenic traits in aestivum spp. Pakistan Journal of Biological Sciences 2: $434-437$.

DOI: https://doi.org/10.3923/pjbs.1999.434.437

10. Dagustu N. (2008). Genetic analysis of grain yield per spike and some agronomic traits in diallel crosses of bread wheat (Triticum aestivum L). Turkish Journal of Agriculture and Forestry 32: 249 - 258.

11. Dhayal L.S. \& Sastry E.V.D. (2003). Combining ability in bread wheat (Triticum aestivum L.) under salinity and normal conditions. Indian Journal of Genetics and Plant Breeding 63: $69-70$. 
12. Dziki D. \& Laskowski J. (2005). Wheat kernel physical properties and milling process. Acta Agrophysica 6: 59-71.

13. Ekiz H., Kiral A.S., Akcin A. \& Simsek L. (1998). Cytoplasmic effects on quality traits of bread wheat. Euphytica 100: 189 - 196.

DOI: https://doi.org/10.1023/A:1018382106978

14. Gaines C.S., Finney P.L. \& Andrew L.C. (1997). Influence of kernel size and shriveling on soft wheat milling and baking quality. Cereal Chemistry 74: $700-704$.

15. Gorjanovic B. \& Balalic M.K. (2005). Inheritance of plant height and spike length in wheat. Genetika 37: 25 - 31 . DOI: https://doi.org/10.2298/GENSR0501025G

16. Griffing B. (1956). Concept of general and specific combining ability in relation to diallel crossing systems. Australian Journal of Biological Sciences 9(4): 463 - 493. DOI: https://doi.org/10.1071/BI9560463

17. Hamada A.A., El-Seidy E.H. \& Hendawy H.I. (2002). Breeding measurements for heading date, yield and yield components in wheat using line $\times$ tester analysis. Annals of Agricultural Sciences Cairo 47: 587 - 609.

18. Iqbal K. \& Chowdhry M.A. (2000). Combining ability estimates for some quantitative traits in five spring wheat (Triticum aestivum L.) genotypes. Pakistan Journal of Biological Sciences 3: 1126 - 1127.

DOI: https://doi.org/10.3923/pjbs.2000.1126.1127

19. Joshi S.K., Sharma S.N., Singhania D.L. \& Sain R.S. (2004). Combining ability in $F_{1}$ and $F_{2}$ generations of diallel cross in hexaploid wheat. Hereditas 141: 115 - 121. DOI: https://doi.org/10.1111/j.1601-5223.2004.01730.x

20. Kumar A., Thakur K.S., Sethi G.S. \& Bhandari J.C. (2003). Combining ability analysis for grain yield and some other morpho-physiological traits in winter $\times$ spring wheat hybrids. Crop Research Hisar 26: 334 - 338.

21. Lyford C., Kidd W., Duarte P.R. \& Deyoe C. (2005). Prediction of flour extraction in a hard red winter wheat using the single kernel characterization. Journal of Food Quality 28: 279 - 288.

DOI: https://doi.org/10.1111/j.1745-4557.2005.00036.x

22. Marshall D.R., Ellison E.W. \& Mares D.J. (1984). Effects of grain shape and size on milling yield in wheat. Theoretical analysis based on simple geometric models. Australian Journal of Agricultural Research 35: 619 - 630.

DOI: https://doi.org/10.1071/AR9840619

23. Marshall D.R., Mares D.J., Moss H.J. \& Ellsion F.W. (1986). Effects of grain shape and size on milling yield in wheat. II. Experimental studies. Australian Journal of Agricultural Research 37: 331 - 342.

24. Mohsenin N.N. (1996). Physical Properties of Plant and Animal Materials, $2^{\text {nd }}$ edition, pp. 758. Gordon and Breach, New York, USA.

25. Shahzad K., Mohy-ud-din Z., Chowdhry M.A. \& Hussain D. (1998). Genetic analysis for some yield traits in Triticum aestivum L. Pakistan Journal of Biological Sciences 1: 237 -240 .

DOI: https://doi.org/10.3923/pjbs.1998.237.240

26. Sharma S.N. \& Sain R.S. (2003). Genetic architecture of grain weight in durum wheat under normal and late sowing environments. Wheat Information Services 96: 28 - 32.

27. Statistical Analysis Systems (SAS) (2002). SAS Version 9.1. SAS Institute Inc., Cary, USA.

28. Steel R.G.D \& Torrie J.H. (1984). Principles and Procedures of Statistics. A Biometrical Approach, pp. 633. McGraw Hill, Books Inc., New York, USA.

29. Topal A., Aydin C., Akgun N. \& Babaoglu M. (2004). Diallel cross analysis in durum wheat (Triticum durum Desf ): identification of best parents for kernel physical features. Field Crops Research 87: 1 - 2 . DOI: https://doi.org/10.1016/j.fcr.2003.08.015

30. Tosun M., Demir I., Server C. \& Gurel A. (1995). Line $\times$ tester analysis in some wheat crosses. Anadolu 5: $52-63$.

31. Yucel C., Baloch F.S. \& Ozkan H. (2009). Genetic analysis of some physical properties of bread wheat grain (Triticum aestivum L.). Turkish Journal of Agriculture 33(1): 525 535 .

32. Zadoks J.C., Chang T.T. \& Konzak C.F. (1974). A decimal code for the growth stage of cereals. Weed Research 14: $415-421$.

DOI: https://doi.org/10.1111/j.1365-3180.1974.tb01084.x 